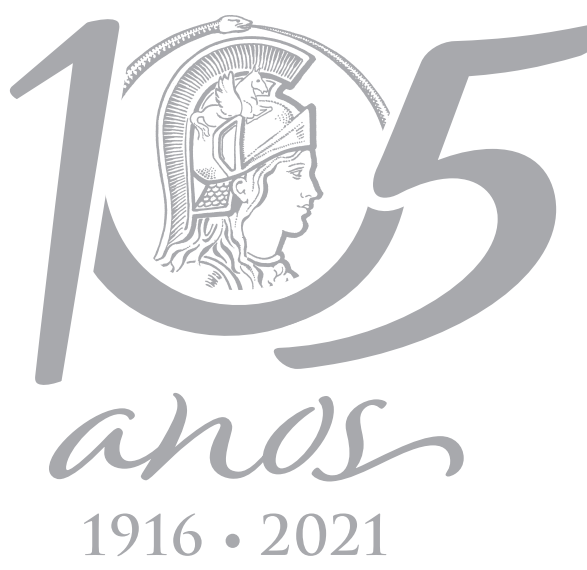

$1916 \cdot 2021$
An Acad Bras Cienc (2021) 93(Suppl. 3): e20201389 DOI 10.1590/0001-3765202120201389

Anais da Academia Brasileira de Ciências | Annals of the Brazilian Academy of Sciences Printed ISSN 0001-3765 I Online ISSN 1678-2690

www.scielo.br/aabc | www.fb.com/aabcjournal

\title{
Misogyny in Brazilian Federal Government Agencies for Science and High-Education
}

\author{
ROBERTA PEIXOTO ARÊAS DA SILVA, CAROLINA ANDRÉA NODARI, \\ MANOEL CARDOSO, ADEMIR E. SANTANA \& MARCIA C. BARBOSA
}

\begin{abstract}
The transformation of women's role in society has been systematically studied. Numerous authors point out that among the factors of extreme relevance to this fact, the main is the increased presence of women in the formal job market. Researches also reveal that the increase in quantity is not reflected equally in all productive sectors nor the egalitarian occupation of high hierarchical positions. The present study aimed to analyze how the presence of women, especially in leadership positions, has evolved at the Brazilian Federal Agency for the Support and Evaluation of Postgraduate Education (CAPES) and the National Council for Scientific and Technological Development (CNPq) over the last 20 years. For these analyzes, surveys were conducted in the people management systems of the Brazilian Federal Public Administration. The initial hypothesis was that female attendance had increased in both the total number of female servants and in management and auxiliary positions, known as DAS in Brazil; however, evidence shows that women reduced overall agency presence, especially in the number of female Analysts occupying DAS positions. These results indicate that the misogyny observed in the academic sphere of the Brazilian National Postgraduate and Science, Technology, and Innovation systems are replicated in the politic-bureaucratic sphere that manages and sponsors these systems.
\end{abstract}

Key words: gender, women, science, agencies.

\section{INTRODUCTION}

Women have historically played a hidden role in the economy by contributing indirectly, not only by taking on most of the household responsibilities but also by performing unpaid activities with a direct impact on the family earnings in the land or family busines (Vadnjal \& Zupan 2009). At the end of the Middle Age, the growth of the cities provided ample possibilities for women to work on their own accounts. They could perform wage labor in households as servants, laundry women, nurses, and sewers. It was the variety of this labor demand, which induced a significant female migration into the towns (Butschek 2006). In the wake of industrialization, almost all young unmarried women outside agriculture used to be engaged in some gainful work outside the home (Goldin 1980). The Second World War because of its dimension impacted on many 
aspects of human rights and, in particular, the relation between men and women (Schweitzer 1980).

Even though some women already performed some form of work before the war, the women's paid labor was restricted mainly to female type of professions, such as typing or sewing, and most women were expected to leave the labor force as soon as they had children, if not as soon as they married (Goldin 2006). The war changed both, the type of work women did and the volume at which they did it. The gap in the labor force created by departing soldiers meant opportunities for women, and it provided unprecedented opportunities to move into occupations previously thought of as exclusive to men. Women took over factories and office jobs that had been held by men (Schweitzer 1980). In some countries, particularly in the United States, women earned more money than women ever did before. Previous to the conflict, women in the US earned $50 \%$ less than the men, but the war changed this reality (Schweitzer 1980).

Single women worked since the Middle Age. Only in the Second World War, the presence of women in the workforce became universal including of married women (Goldin 2006). After the war, the government worried that when men returned from military service, there would be no jobs available for them, and admonished women to return to the activities at home. Therefore, many women were laid off in large numbers at the end of the war. Despite the stereotype, the war solidified the notion that women were in the workforce to stay. However, they were paid less and the sexism once again dominated again the workplace (Acemoglu et al. 2004). The same institutions and economic sectors, which promoted the work of women during the war, got together to suppress the female participation in some sectors. This view was supported by conservative political and religious groups which understood the women's independence as a threat to the white androcentric (male-dominant) system. They promoted misogynistic adds and propaganda stimulating women to return to the housework. Some women, however, understood the power of economic independence and they stayed working in factories, offices and to the government (Milkman 1987). The dispute between men and women for the production space became fierce and even today constitutes a reality that negatively impacts the organization of modern societies (Blau et al. 2002, Acemoglu et al. 2004).

This labor field dispute is unequal. The labor market is structurally androcentric because rules have been, and are still created, maintained, and supervised primarily by men who, knowingly or unknowingly, perpetuate adverse conditions for female labor. This adversity, which is not always obvious, is observed, for example, in weekly working hours. Despite the fact that formal working hours are the same for both sexes, women are subjected to double or triple hours, as they are still primarily responsible for childcare and home care (Riforgiate \& Boren 2015). In addition to imposing this burden, which in itself is a barrier, often, women who want to become mothers have to choose between paid work and motherhood. Governments and businesses rarely offer sufficient and specific support for families to cope with the demands of the first few years of children $s$ lives. This insufficiency can be observed in studies that indicate the lack of public daycare, and the non-compulsory paid maternity leave, as seen in the United State (Adema et al. 2016).

Even with these and many other challenges, women are occupying a considerable part of the workforce. If at the beginning of the twentieth century it was estimated that they accounted for $20 \%$ of paid workers (Leser 1958), in 1990, 
they accounted for an average of $39 \%$ of the labor market composition of the 215 countries and territories assessed by the Bank Worldwide. However, it is surprising to find that almost 30 years later, in 2018, this average percentage $\mathrm{s}$ the same as $39 \%$. In some countries, female participation has increased, such as in Brazil and the United States, where rates increased from $43 \%$ to $45 \%$ and from $44 \%$ to $46 \%$, respectively. On the other hand, in other countries, such as China and India, millions of women left formal paid work hours. Consequently, their participation in the paid labor market dropped from $45.2 \%$ to $43.6 \%$, and from 25\% to 22.0\% (Bank 2019).

In addition to the low proportion of women in the workforce, the equity of labor remuneration has yet to be debated. At the beginning of the last century, Goldin documented that, in the United States, working women received, on average, half of the men's remuneration (Goldin 2006). This result is confirmed by dozens of studies that claim that the gender pay gap is still a reality in the world (Dozier et al. 2013). The additional problem is that women do not occupy the positions of command, either in public or private companies, in the same proportion as men. One might misleadingly believe that the first situation explains the second, but it is not the case. The pay gap is present both on the vertical and horizontal career paths since, in the same hierarchical positions, female workers receive, on average, 20\% less than men (Office 2018). In other words, women are not welcome to decision making spaces, if they insist and reach there, they will not receive fair remuneration.

Data from The Global Gender Gap Report, produced by the World Economic Forum, reveal that by 2018 out of the 149 countries assessed, there were only 17 in which heads of state were women, while, on average only $18 \%$ of ministers and $24 \%$. of parliamentarians are women. In addition, women hold only $34 \%$ of managerial positions in the countries where data are available, and less than $7 \%$ in the four worst performing countries in this criteria (Egypt, Saudi Arabia, Yemen, and Pakistan) (Forum 2018). There is a clear, old and persistent process of excluding women from decision-making spaces, called glass ceiling by many authors (Morrison et al. 1987).

The misogyny ${ }^{1}$ described above is present in the Brazilian reality. In McKinseys serial studies, which compare the diversity in leadership positions of companies from different countries, highlight a misogyny reality in Brazil, on average, in corporate board (Devillard et al. 2013) and in executive team there are only $6 \%$ of women (Hunt et al. 2015).In other words, Brazilian women tend to occupy the beginning of their careers, while the hierarchically superior positions that depend on political appointment or articulation are mostly male. According to the report by Grant Thornton International Business Report 2016, for the period 2012-2016, there has been a worsening of issues of female leadership in some Latin American countries, including Brazil (Lagerberg 2016).

In the public service where equality is expected, since admission occurs through public contests, however the indexes found also reveal the glass celing. The following proportions of women are registered: 51.8\% general population (IBGE 2019), 49\% economically active population (Palotti \& Alessandro 2015), 46\%

\footnotetext{
${ }^{1}$ Misogyny in this paper is understood as the concept offered by Morgan-Curtis in the book International encyclopedia of men and masculinities: "Misogyny is the hatred of women. Though most common in men, misogyny also exists in and is practiced by women against other women or even themselves. Misogyny functions as an ideology or belief system that has accompanied patriarchal, or male-dominated, societies for thousands of years and continues to place women in subordinate positions with limited access to power and decision-making" (Flood et al. 2007).
} 
federal civil servants, $43 \%$ occupying DAS $^{2}$ positions. However, if the DAS positions are stratified at its six levels, women occupy only 19\% of the level 6 positions, the highest in the hierarchy (Palotti \& Alessandro 2015). Varzola Vaz found similar data in 2010 (Vaz 2010). In a survey evaluating DAS occupation from 1997-2008, stratifying at levels 1 to 6 , it was identified that in the first year evaluated, women, occupied $45.3 \%$ of the lowest hierarchical level (DAS -1) and 14.4\% of the highest (DAS - 6), while in the last year, the values were $45.5 \%$ and $20.0 \%$, respectively (Vaz 2010).

In addition to vertical exclusion, glass ceiling, there is another complementary process, the horizontal exclusion, which keeps women away from certain areas of society. For instance, around the world, in the military forces the female presence is low as in France (13.1\%), Canada (12.5\%), Spain (10.5\%), England (9\%), Netherlands (8.5\%) arriving almost null in Brazil (1.3\%) (Lombardi et al. 2009). When assessing the police force in all Brazilian states, Musumeci \& Soares (Musumeci \& Soares 2004) described the average proportion of women as $19.6 \%$ in the state civil police, $10 \%$ in the federal police and $6 \%$ in the military police ${ }^{3}$.

Horizontal exclusion is found when assessing the presence of women and specific areas of study and research. Studying the distribution of professors at a recognized Brazilian university, UNICAMP, Moschkovich and Almeida Moschkovich \& Almeida 2015 identified both vertical and horizontal exclusion. Considering the total number of university professors, women accounted for $37 \%$, but the distribution through the areas of knowledge is unequal, considering the subgroup of STEM field, this percentage drops to $22 \%$. In addition, only for $26.2 \%$ of the group represent who reached the top of the career.

In some structuring areas of science, such as Physics, several studies have reported similar scenarios. Evaluating, among several parameters, the granting of scientific initiation, master's and doctorate scholarships, Saitovitch and collaborators (Saitovich et al. 2015) identified that there was no widespread and significant progress over the 12 years studied. However, in the first level, in scientific initiation there was progress in one of the modalities, the rate went from $23 \%$ to $37 \%$, that of granting a doctoral scholarship remained unchanged, remaining in the low percentage of $18 \%$.

Stefanello and collaborators (Lima et al. 2016) found in 2014 the rates of $33 \%, 23 \%$, and $22 \%$, respectively, confirming underrepresentation in this area since the initial levels of the academic career. Considering the 2011-2015 period, in the area of Astronomy and Physics, women represented $13 \%$ of postgraduate professors, $12.5 \%$ of coordinators of postgraduate courses and had not occupied the post of CAPES Area Coordinator.

Gender equity studies about researchers and professors are quite common. Overall, they indicate similar results, identifying the academic field as a misogynist environment (Areas et al. 2020). However, the situation of the careers of female professionals who work in the management of postgraduate, science, and technology systems has been little discussed.

\footnotetext{
${ }^{2}$ DAS stands for senior management and assessor group, that is, leadership and advisory positions in the Brazilian Federal Public Administration (APF in Portuguese), direct, autarchic and foundational. These positions are filled by designation, are transitory and can be filled by public servants or by people who have no permanent employment relationship with APF.

${ }^{3}$ Internationally, military police designate the corporation that exercises police power within the armed forces. In Brazil it is different, the Military Police (PM in Portuguese) has the function of using the general policing of civilians and military.
} 
In Brazil, management of the postgraduate programs and the science and technology system are interdependent and coordinated by two different agencies. Both systems are maintained almost entirely by the government, at its state and federal levels. In this circuit, two agencies of the federal government stand out for being responsible for setting priorities and fostering the development of Brazilian science, the Brazilian Federal Agency for the Support and Evaluation of Graduate Education (CAPES - in Portuguese) and National Council for Scientific and Technological Development (CNPq in Portuguese), the first linked to the Ministry of Education and the second to the Ministry of Science, Technology, Innovation, and Communication. Its staff consists essentially of servers approved by public tender. These servants belong to the Federal Government Science and Technology career. They have in their scope of duties to develop, in partnership with university professors and researchers, the strategic plans and public policies that will guide the development of this area in the country.

At this point, it is necessary to explain a little the responsibilities of this instance. The decisions are taken within the scope of the agencies impact on the execution of government investments, either by granting a scholarship or project financing. Individuals who occupy command positions can include or exclude themes, initiatives, and notices, and those who carry them out, factory floor bureaucrats, when making small adjustments at the cutting edge, also co-define these actions, facilitating or hindering implementations. Oliveira (Oliveira 2012) discusses this complex relationship of the bureaucrat and the success of public policy well. For now, it is essential to remember that they are fundamental players because Graduate
Studies and Science and Technology make up policies, which in the Brazilian case, are mostly public, hence the importance of understanding the dynamics of this micro-society.

In this context, the present study aims to identify how the presence of women, mainly in management positions, in the Brazilian Federal Agency for the Support and Evaluation of Postgraduate Education (CAPES) and in the National Council for Scientific and Technological Development (CNPq) evolved in the last 20 years. The analysis of the evolution of the percentage of women at positions in these two agencies as far as we know is new in the literature. The aim is to illustrate how percentage of women decreases as the position becomes more prestigious (vertical exclusion) and also decreases as the same position gains power (horizontal exclusion). The remaining of the work goes as follows. In the section 2, the metodol-ogy is presented, section 3 shows our results and discuss the main evidences observed. Section 4 brings the solutions.

\section{METHODOLOGY}

For the execution of the present study, a historical survey ${ }^{4}$ of the number of public servants in the Career of Science and Technology was carried out. Two groups were selected: the staff at the CAPES and CNPq funding agencies. The analysis covers the time frame from 1999 to 2018, consider only active (retired servants was not considered, with the exception of the retired individual who held a DAS position, in this case, it was recorded in the DAS occupants table and graph). Information from mid-level professionals, the assistants, and higher-level professionals. The CAPES data were requested directly from the Foundation

\footnotetext{
${ }^{4} \mathrm{An}$ article or portion of an article giving an account of past events or circumstances significant in a field of study, a profession, a discovery, an invention.
} 
Management Board, and the CNPq data were required through the Electronic Citizen Information Service System (e-SIC), under the Law on Access to Information 5 , under the number of protocols 01390.0001082/2019-37 and 01390.001738/2020-62.

The information sent by the agencies indicated the number in each group by year, category mid-level servants (assistants)/higher-level servants (analysts), and DAS occupation (considering levels 1 to 6) stratified by sex. The sex information is part of the personnel record of each institution; in other words, there was no manual interference by the researchers.

In the first year of the time series, CNPq had 1185 servers in its staff, in the last year analyzed, this value was reduced to 428 . In the opposite movement, at the beginning of the series, CAPES had 130 public servants; in the end, this number increases to 361 . In the analyzes, the proportions of women in each studied group were compared; therefore, it was not necessary any type of standardization.

It is important to clarify that the DAS occupants combines individuals who may or may not be public servants. But even when they are not public servants when the individual starts to occupy the position, he fills out a register, so it was possible to obtain the information of all the people who occupied DAS positions, even those who do not have a permanent link with the Federal Public Administration.

The duties of those who occupy a DAS are twofold, management, or assessor. The first refers to the group that coordinates teams of all sizes, natures, and functions. This roll includes Presidents of Agencies, Directors of Public Foundations, Coordinators and Heads of Division. The second group is made up of people who directly assist these managers and politicians in the performance of their activities, without their own attributions and management competencies.

\section{RESULTS AND DISCUSSION}

Figure 1 illustrates the percentage of male (green) and female (yellow) staff from CAPES from 1999 to 2018. In this graph only public employees are included. CAPES is an organization inside the ministry of education, and upon its foundation until 1996, the workforce used to come from this ministry. After 1997, the agency started to select the personnel by a specific public contest to Science and Technology Careers. The majority of women in the staff at the beginning of the time series can be explained because usually, the Education field is dominated by professionals with a background in educational studies, which in turn consists of the majority of women.

The graph also shows an increase in the percentage of men, particularly starting in 2008. The origin of this growth has two complementary reasons: the independence on hiring (specific contests in the Science and Technology field) and the global growth of CAPES in institutional terms. Over the years, CAPES, instead of receiving the personnel from other areas of the ministry, could organize its own entrance competition

\footnotetext{
${ }^{5}$ Law No. 12,527 / 2011, known in Brazil as the Access to Information Law (LAI), regulates the constitutional right of access to public information. This standard came into force on May 16, 2012, and created mechanisms that make it possible for any person, physical or legal, without having to present a reason, to receive public information from the agencies and entities. The Law applies to the three branches of the Union, States, Federal District, and Municipalities. Private non-profit entities are also required to advertise information regarding the receipt and destination of public funds received by them. Citizens interested in receiving the information must physically search for the agency of interest or access the websites made available by the government. In the case of the Federal Government, this service is available at http://www.acessoainformacao.gov.br/assuntos/conheca-seu-direito/a-lei-de-acesso-a-informacao.
} 

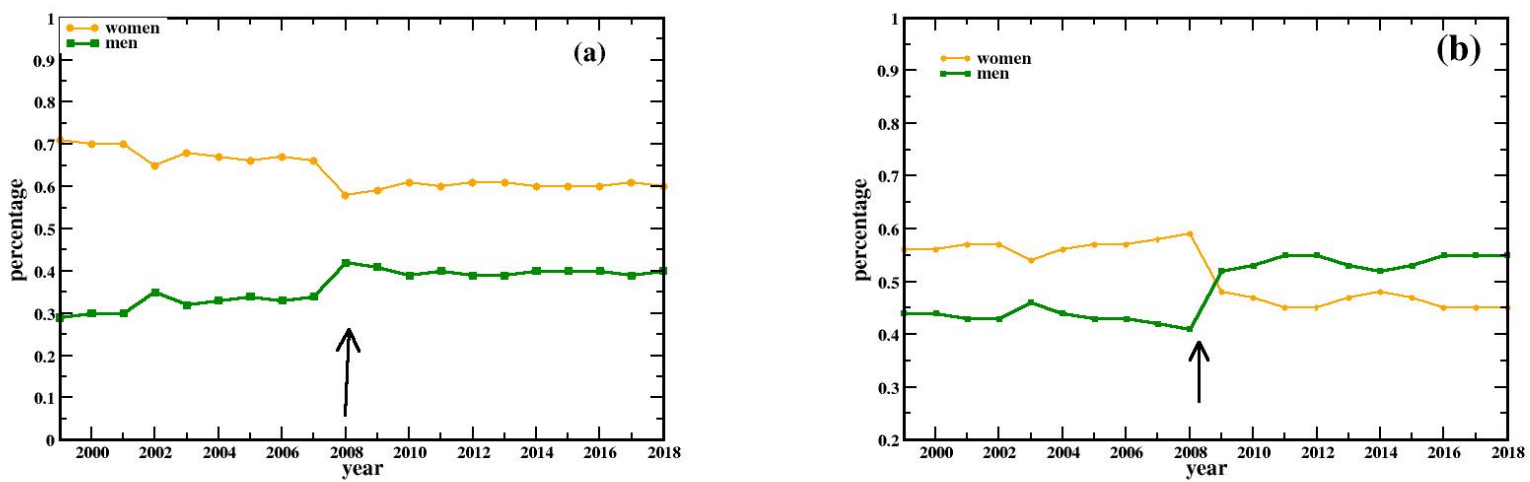

Figure 1. Percentage of male (green squares) and female (yellow circles) CAPES (a) analysts and (b) assistants versus time. The arrow shows the period of time in which there was an increase in the budget and in the number of analysts and assistants as shown in the Table I. This data only includes public employees. [Source: Data from Capes].

(an exam for selecting the personnel which is the method for hiring in the Brazilian public service) attracting another profile of professionals. Besides that, the organization has grown in power and size, especially since 2007, when receiving an additive mission promotes the training of primary and secondary school teachers.

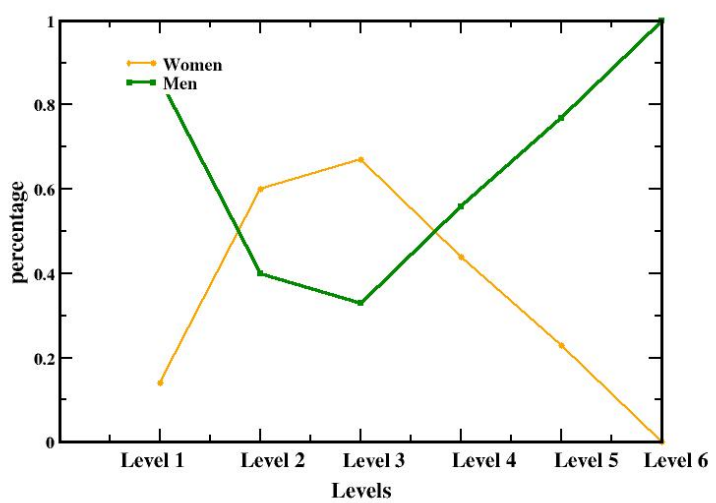

Figure 2. Percentage of male (green squares) and female (yellow circles) CAPES personal with DAS for distinc DAS positions: from lower to the upper levels from 1 to 6. [Source: Data from Capes].

This new assignment resulted in a significant increase in budget (Capes 2020) and political status. Table I shows the increase of budget and of the number of staff. The organization has grown in power and size, especially since 2007, when receiving an additive mission promotes the training of primary and secondary school teachers. This new assignment resulted in a significant increase in budget and political status and not by coincidence, also the growth of male participation in CAPES human resources. When a filed is underappreciated, the occupation by women does not bother and is even encouraged; an example is what happened in the field of computer science.

One example in which this happened before was information technology (IT) courses. In the past IT had a significant number of women among their students. However, as computing became an instrument of economic and cultural power, women became a minority. In 1991, women represented $37 \%$ of the professionals in the area, in 2015, this number dropped to approximately $25 \%$. And there is still the internal distortion of the area, in the operational positions they occupy about 51\%, in the engineering and development sectors the proportion reaches $13 \%$ of women (Ashcraft et al. 2016). 
Table I. Percentage of women and total number of Capes analysts and assistants and total budget from 1999 to 2018. This data only includes public employees. [Source: Data from Capes].

\begin{tabular}{|c|c|c|c|c|c|}
\hline Year & $\begin{array}{c}\text { Percentage } \\
\text { Women Analysts }\end{array}$ & $\begin{array}{c}\text { Percentage } \\
\text { Women Assistants }\end{array}$ & $\begin{array}{c}\text { Total Number } \\
\text { Analysts }\end{array}$ & $\begin{array}{c}\text { Total Number } \\
\text { Assistants }\end{array}$ & $\begin{array}{c}\text { Budget } \\
\text { Billion Reais }\end{array}$ \\
\hline 1999 & 0.70 & 0.56 & 82 & 50 & - \\
2000 & 0.70 & 0.56 & 80 & 50 & 0.452 \\
2001 & 0.70 & 0.57 & 81 & 51 & 0.514 \\
2002 & 0.66 & 0.57 & 100 & 51 & 0.478 \\
2003 & 0.68 & 0.54 & 96 & 50 & - \\
2004 & 0.67 & 0.56 & 101 & 48 & 0.579 \\
2005 & 0.66 & 0.57 & 100 & 47 & 0.671 \\
2006 & 0.67 & 0.57 & 97 & 47 & 0.742 \\
2007 & 0.66 & 0.58 & 95 & 45 & 0.814 \\
2008 & 0.58 & 0.59 & 178 & 44 & 1.260 \\
2009 & 0.59 & 0.48 & 219 & 122 & 1.659 \\
2010 & 0.61 & 0.47 & 221 & 117 & 2.010 \\
2011 & 0.60 & 0.45 & 211 & 104 & 2.703 \\
2012 & 0.61 & 0.45 & 204 & 96 & 3.522 \\
2013 & 0.61 & 0.47 & 265 & 156 & 4.772 \\
2014 & 0.60 & 0.48 & 260 & 139 & 5.337 \\
2015 & 0.60 & 0.47 & 252 & 139 & 7.016 \\
2016 & 0.60 & 0.45 & 250 & 132 & 5.899 \\
2017 & 0.61 & 0.45 & 239 & 130 & 4.682 \\
2018 & 0.60 & 0.45 & 234 & 127 & 3.837 \\
\hline
\end{tabular}

The mechanisms that work to attract male labor to environments with a greater concentration of power may be associated with increased competitiveness that, in the terms that is normally presented, excludes women. This process described earlier is known as horizontal exclusion. This type of exclusion deals with the mechanisms that segment social spaces as "male" and "female" marking, for example, the careers and fields of knowledge. According to Olinto's (Olinto 2011) definition, “Through horizontal segregation, women are made to make choices and follow paths markedly different from those chosen or followed by men. Especially due to the performance of the family and the school, girls tend to evaluate themselves as more apt to carry out certain activities and to establish strategies for themselves. More compatible with what they consider or are led to believe as more suitable for them. Horizontal segregation includes mechanisms that make career choices markedly segmented by gender. Like the female professions tend to be less valued in the labor market". But it is not only 
Table II. Percentage of women Capes DAS analysts (public employees), DAS assistants (public employees), DAS not staff (not public employees) and total number of DAS analysts (public employees) and DAS assistants (public employees) from 1999 to 2018. [Source: Data from Capes].

\begin{tabular}{|c|c|c|c|c|c|c|}
\hline Year & DAS Analyst & DAS Assistant & DAS Not Staff & DAS Analyst & DAS Assistant & DAS Not Staff \\
Women (\%) & Women (\%) & Women (\%) & Total & Total & Total \\
\hline 1999 & 0.71 & 0.30 & 0.54 & 17 & 10 & 26 \\
2000 & 0.84 & 0.30 & 0.54 & 19 & 10 & 24 \\
2001 & 0.80 & 0.30 & 0.55 & 20 & 10 & 22 \\
2002 & 0.75 & 0.22 & 0.55 & 24 & 9 & 20 \\
2003 & 0.75 & 0.25 & 0.60 & 28 & 12 & 10 \\
2004 & 0.69 & 0.43 & 0.45 & 29 & 14 & 11 \\
2005 & 0.68 & 0.36 & 0.50 & 28 & 14 & 12 \\
2006 & 0.66 & 0.43 & 0.14 & 29 & 14 & 7 \\
2007 & 0.61 & 0.43 & 0.33 & 31 & 14 & 9 \\
2008 & 0.72 & 0.45 & 0.49 & 32 & 11 & 37 \\
2009 & 0.74 & 0.44 & 0.55 & 35 & 9 & 40 \\
2010 & 0.71 & 0.36 & 0.51 & 41 & 11 & 37 \\
2011 & 0.68 & 0.42 & 0.47 & 40 & 12 & 34 \\
2012 & 0.62 & 0.58 & 0.41 & 58 & 12 & 27 \\
2013 & 0.59 & 0.50 & 0.52 & 59 & 14 & 27 \\
2014 & 0.57 & 0.54 & 0.59 & 65 & 13 & 27 \\
2015 & 0.57 & 0.54 & 0.48 & 65 & 13 & 23 \\
2016 & 0.55 & 0.54 & 0.57 & 65 & 13 & 21 \\
2017 & 0.55 & 0.43 & 0.59 & 66 & 14 & 22 \\
2018 & 0.49 & 0.41 & 0.60 & 65 & 17 & 20 \\
\hline
\end{tabular}

this type of exclusion that women are subjected to, there is also vertical exclusion, also known as glass ceiling. This is an expression used to designate the invisible barriers faced by women to ascend to leadership and decision-making positions (Morrison et al. 1987). In order to verify the presence of glass ceiling in CAPES, the occupation of DAS positions in the 20 years analyzed was evaluated as illustrated in the Table II. Figure 2 illustrates the percentage of men and women in a the different levels from
1 to 6 (the lowest to the highest) as DAS at Capes over the period of time analyzed in this paper. Here both DAS which are Capes staff (public employees) and non-staff (not public employees) were employed. The graph shows a scissors effect was found, that is, in the positions of the lower hierarchy, women are present in greater numbers, in the positions of the higher hierarchy they are lesser numbers . In addition to giving the graph the shape of a scissors, the idea of exclusion is clear with this expression. 

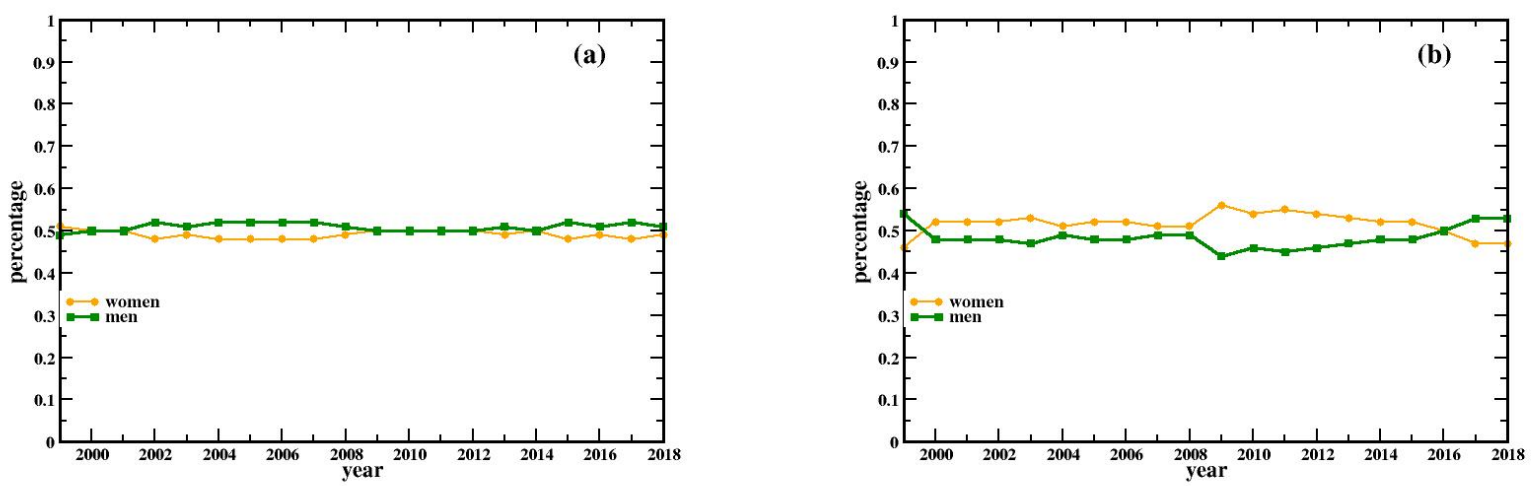

Figure 3. Percentage of male (green squares) and female (yellow circles) CNPq (a) analysts and (b) assistant over time from 1999 to 2018. This data only includes public employees. [Source: Data from CNPq].

Next, we investigated the participation of women as staff members of the grant agency CNPq illustrated in the Figure 3 for the analysts and assistants. In the case of this agency, there is no gender bias at any level or time between the distribution of staff either analysts or assistants, without or with DAS, as illustrated in Table III and Table IV. In order to analyze the differences between the two agencies, it is essential to consider the dynamics of growth and shrinkage of the institutions in recent years. CAPES capitals, taken as an accumulation of resources, economic, political and power, have been multiplied in recent decades, while CNPq, on the contrary, has been slowly losing them. Despite the fact that CNPq also participated in the internationalization program Science without Borders as CAPES, which received a substantial investment from the federal government, throughout the historical series, there was a real loss of its budget.

In 2002, the total budget was approximately $\mathrm{R} \$ 630$ million, in 2018, this amount was R\$ 984 million. Although nominally higher, when deflating the value of 2002 by the INPC index (national consumer price index), it is observed that the 2002 budget in 2018 was equivalent to $\mathrm{R} \$ 1.6$ million, that is, there was a real loss of $38 \%$ of the agency's investment. In addition, there was a loss in its staff, at the beginning of the historical series, the Ministry of Science and Technology agency welcomed 1185 servants in its staff, in the last year analyzed, this amount was reduced to 428 . Collaborating for a situation of retraction of the institution since the 1980s, new National Science and Technology System decision-making and financing centers have been created, including a Ministry, a fact that has slowly modified the system's power centers. Since its creation in 1985, Ministry of Science and Technology started a process of incorporating and centralizing the planning and management of national policies in the area, responsibilities that, at least in part, belonged to the scope of CNPq. It can be said that, in its totality, the National Science and Technology System also had its capital increased in the studied period, however, the mechanisms by which this happened, caused the emptying of the Council, which started to have its functions and part of its budget capillarized in several new government bodies and institutions.

When analyzing the distribution of DAS positions according to gender in CNPq as shown 
in the Figure 4. In fact, glass ceiling has been shown to be resistant, resilient and generalized in several studies of the literature. According to Vesola (Vaz 2010), there are two main theoretical lines to explain this inequality. One of these is structured based on women's late formal education. According to the thinkers of this line, it would be a more technical issue, women entered the educational institutions late, mainly in those of higher quality, and for this reason, they did not obtain the necessary training to occupy high hierarchical positions. A second group is based on the unequal division of domestic work, which gives women the greatest number of hours dedicated to the care of the home and family. Still according to this actor, these two mechanisms can act in a complementary way and add to so many others.

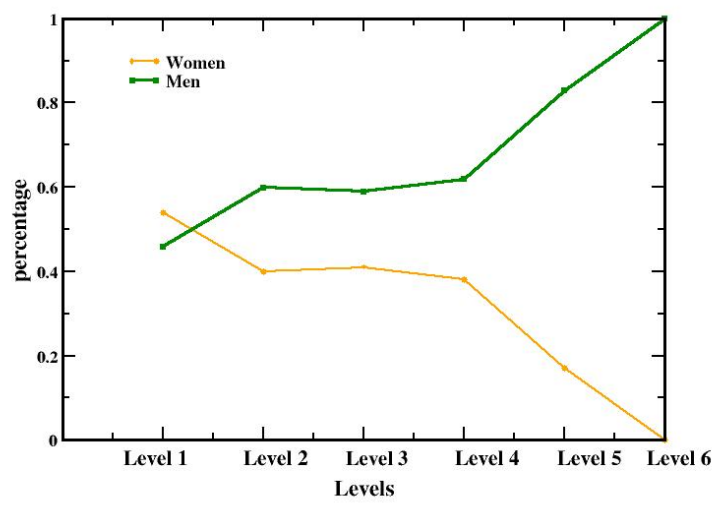

Figure 4. Percentage of male (green squares) and female (yellow circles) CNPq personal with DAS for distinc DAS positions: from lower to upper levels from 1 to 6. [Source: Data from CNPq].

Considering the first theoretical line, would be very intuitive that, as women increase their education, what is a fact in the last decades, and attendance to great educational institutions, this limitation can be overcome. But this was not observed. During its 69 years of existence, CAPES had only 3 (three) women occupying the Presidency (DAS level 6), Ms.
Suzana Gonçalves (1964 to 1966), Profa. Eunice Ribeiro Durham (1990 - 1992 and 1995) and Profa. Maria Andrea Loyola (1992 to 1994). None of these female leaderships has occurred in the past 25 years. CNPq, in turn, never had a presidency, as women had their maximum expression of representativeness by two vice-presidencies, a Profa. Alice Rangel de Paiva Abreu (1999 to 2002) and Profa. Wrana Panizzi (2007 to 2011). In addition, since 2003, the majority of qualified Pd. D. in the country are women (CGEE 2010). Admittedly, postgraduate courses are concentrated in public universities, as well as the best in the country and, before becoming the majority, attendance naturally already occurs in approximate proportions. There seems to be no cause correlation between schooling and female presence in the spheres of power.

The issue of the unequal division of domestic work may be a factor. Still, it would not justify the presence of women in DAS level 3 positions in more significant numbers at CAPES and in a slightly lower proportion at CNPq. These positions demand effort similar to the higher levels; however, they differ due to the scope of their decision-making and the political strength attributed to them. In this sense, the discussion proposed by Lüchmann and Almeida (Lüchmann \& Almeida 2010), seems to bring a more significant contribution. According to these authors, "ccupying the highest DAS positions (DAS 4, DAS 5, and DAS 6) progressively requires the indication, influence, and political ability. When it comes to the Political Field, women perish, because this field demands, in addition to great investment of time, coping with disappointments and frequent hostilities such as oppositions, personal attacks, and other anxieties that affect men and women in different ways".

In this sense, expanding the look at cultural issues, how men and women are educated, 
Table III. Percentage of women and total number of CNPq analysts and assistants from 1999 to 2018. This data only includes public employees. [Source: Data from CNPq].

\begin{tabular}{|c|c|c|c|c|}
\hline Year & $\begin{array}{c}\text { Pecentage } \\
\text { Women Analysts }\end{array}$ & $\begin{array}{c}\text { Percentage } \\
\text { Women Assistants }\end{array}$ & $\begin{array}{c}\text { Total } \\
\text { Women Analysts }\end{array}$ & $\begin{array}{c}\text { Total } \\
\text { Number Assistants }\end{array}$ \\
\hline 1999 & 0.51 & 0.46 & 428 & 757 \\
2000 & 0.50 & 0.52 & 307 & 399 \\
2001 & 0.50 & 0.52 & 309 & 431 \\
2002 & 0.48 & 0.52 & 379 & 414 \\
2003 & 0.49 & 0.53 & 385 & 387 \\
2004 & 0.48 & 0.51 & 449 & 439 \\
2005 & 0.48 & 0.52 & 442 & 424 \\
2006 & 0.48 & 0.52 & 435 & 431 \\
2007 & 0.48 & 0.51 & 425 & 426 \\
2008 & 0.49 & 0.51 & 416 & 414 \\
2009 & 0.50 & 0.56 & 383 & 297 \\
2010 & 0.50 & 0.54 & 359 & 279 \\
2011 & 0.50 & 0.55 & 376 & 313 \\
2012 & 0.50 & 0.54 & 374 & 320 \\
2013 & 0.49 & 0.53 & 351 & 289 \\
2014 & 0.50 & 0.52 & 323 & 261 \\
2015 & 0.48 & 0.52 & 308 & 242 \\
2016 & 0.49 & 0.50 & 290 & 222 \\
2017 & 0.48 & 0.47 & 264 & 195 \\
2018 & 0.49 & 0.47 & 253 & 175 \\
\hline
\end{tabular}

how society stimulates the development of each one according to the gender to which they belong, including the facilities and barriers that are placed to them, seems to be the key to understand the processes of horizontal and vertical exclusion imposed on women and which were once again confirmed in this research. As a result, we also emphasize that this discussion must be taken to the governments, indeed public policies aimed at gender equity and transversal gender-inclusive methodologies can promote and accelerate the cultural transformations necessary to change the described social structures (Dufour et al. 2017).

\section{CONCLUSIONS}

In this paper, we analyzed the percentage women working at two Brazilian grant agencies, CAPES and CNPq, at different positions from 1999 to 2018. At CAPES, the percentage of women decreased as the agency increased in size and budget, indicating that men usually are attracted 
Table IV. Percentage of women CNPq DAS analysts (public employees), DAS assistants (public employees), DAS not staff (not public employees) and total number of DAS analysts (public employees), DAS assistants ( public employees) and DAS not staff (not public employees) from 1999 to 2018. [Source: Data from CNPq].

\begin{tabular}{|c|c|c|c|c|c|c|}
\hline Year & $\begin{array}{c}\text { Percentage } \\
\text { Women Analysts }\end{array}$ & $\begin{array}{c}\text { Percentage } \\
\text { Women Assistants }\end{array}$ & $\begin{array}{c}\text { Percentage } \\
\text { Women Non Staff }\end{array}$ & $\begin{array}{c}\text { Total Number } \\
\text { Analysts }\end{array}$ & $\begin{array}{c}\text { Total Number } \\
\text { Assistants }\end{array}$ & $\begin{array}{c}\text { Total Number } \\
\text { Non Staff }\end{array}$ \\
\hline 1999 & 0.49 & 0.45 & 0.44 & 86 & 42 & 34 \\
2000 & 0.49 & 0.48 & 0.40 & 63 & 25 & 5 \\
2001 & 0.48 & 0.48 & 0.33 & 62 & 27 & 3 \\
2002 & 0.49 & 0.54 & 1.00 & 65 & 26 & 1 \\
2003 & 0.46 & 0.48 & 1.00 & 59 & 31 & 2 \\
2004 & 0.43 & 0.48 & 0.75 & 60 & 27 & 4 \\
2005 & 0.45 & 0.46 & 0.67 & 64 & 24 & 3 \\
2006 & 0.48 & 0.54 & 0.50 & 64 & 26 & 4 \\
2007 & 0.46 & 0.56 & 1.00 & 68 & 25 & 1 \\
2008 & 0.47 & 0.54 & 0.00 & 66 & 26 & 0 \\
2009 & 0.42 & 0.57 & 0.00 & 67 & 23 & 0 \\
2010 & 0.41 & 0.48 & 0.00 & 66 & 25 & 0 \\
2011 & 0.44 & 0.42 & 0.67 & 63 & 26 & 3 \\
2012 & 0.43 & 0.43 & 0.50 & 65 & 28 & 2 \\
2013 & 0.42 & 0.42 & 1.00 & 65 & 26 & 2 \\
2014 & 0.44 & 0.44 & 0.67 & 64 & 27 & 3 \\
2015 & 0.47 & 0.39 & 0.50 & 64 & 28 & 6 \\
2016 & 0.48 & 0.41 & 0.20 & 56 & 27 & 3 \\
2017 & 0.43 & 0.36 & 0.33 & 64 & 28 & 3 \\
2018 & 0.55 & 0.40 & 0.33 & 69 & 3 \\
\hline
\end{tabular}

to jobs involving power. In the particular case of DAS positions, in CAPES and CNPq it becomes clear the scissors' effect.

The misogyny of the Brazilian Academy, already discussed in a previous study (Areas et al. 2019) is also found in the political/bureaucratic field of the Brazilian Postgraduate System and Science and Technology System. Bourdieu argues that this scenario is the result of social construction in which women are convinced through the symbolic sphere that submission is their natural place (Bourdieu 1999). Studies that show no biological differences, specifically cognitive that justify this misogynistic practice (Bian et al. (2017)) support the imputation suggested by the sociologist and encourage the revision of current social constructs. It is necessary that the mechanisms perpetuating this reality be revealed and policies to combat horizontal and vertical exclusions be developed and institutionalized. 


\section{Acknowledgments}

The authors express their gratitude to the Conselho Nacional de Desenvolvimento Científico e Tecnológico (CNPq) and the Coordenação de Aperfeiçoamento de Pessoal de Nivel Superior (CAPES) for sharing the data and for finantial support.

\section{REFERENCES}

ACEMOGLU D, AUTOR DH \& LYLE D. 2004. Women war and wages: The effect of female labor supply on the wage structure at midcentury. J Polit Econ 112: 497-551.

ADEMA W, CLARKE C \& FREY V. 2016. Paid parental leave and other supports for parents with young children: The united states in international comparison. Int Soc Secur Rev 69: 29-51.

AREAS R, ABREU A, NOBRE C, SANTANA AE \& BARBOSA MC. 2020. Gender and the scissors graph of brazilian science: from equality to invisibility. https://osf.io/ m6eb4 Accessed: 05-06-2021.

AREAS R, BARBOSA MC \& SANTANA AE. 2019. Teorema de emmy nother, 100 anos: Alegoria da misogenia em ciência. Rev Bras Ens Fis 41: e20190017.

ASCHCRAFT C, MCLAIN B \& EGER E. 2016. Women in tech: The facts. https://www.ncwit.org/sites/default/files/ resources/ncwit_women-in-it_2016-fullreport_finalweb06012016.pdf. Accessed: 05-08-2020.

BANK TW. 2019. Labor force female (\% of total labor force) 1990-2018. http://databank.worldbank.org/ reports.aspxsource $=28 \&$ series $=$ SL.TLF.CACT.ZS \& country $=$. Accessed: 18-09-2019.

BIAN L, LESLIE SJ \& CIMPIAN A. 2017. Gender stereotypes about intellectual ability emerge early and influence children's interests. Science 355: 389.

BLAU L, FERBER MA \& WINKLER AE. 2002. The Economics of Women, Men, and Work. Pearson, New Jersey.

BOURDIEU P. 1999. Dominação Masculina. M. H. Kuhner, Trans., Rio de Janeiro.

BUTSCHEK F. 2006. The role of women in industrialization. https://pdfs.semanticscholar.org/ b65c/52edc470a155a60c538ef1b6fa1335c63925.pdf.

Accessed: 23-10-2029.

CAPES. 2020. Orçamento - evolução em reais. https: //www.capes.gov.br/orcamento-evolucao-em-reais. Accessed: 05-08-2020.

CGEE. 2010. Cgee doutores 2010: Estudos demografia da base técnico-científica brasileira. https://www.
cgee.org.br/documents/10195/734063/Doutores2010_ demografiall_02052012_7842.pdf. Accessed: 05-08-2020.

DEVILLARD S, SANCIER S, WERNER C, MALLER I \& KOSSOF C. 2013. Women matter - gender diversity in top management: Moving corporate culture, moving boudaries. https://www.mckinsey.com/ /media/ McKinsey/Featured\%20Insights/Women\%20matter/ Addressing\%20unconscious\%20bias/WomenMatter\% 202013\%20Report\%20(8).ashx. Accessed: 23-10-2019.

DOZIER DM, SHA BL \& SHEN H. 2013. Why women earn less than men: the cost of gender discrimination in U.S. public relations. Public Relat J 7: 1-21.

DUFOUR P, SCALA F \& PATERSON S. 2017. Gendering public policy or rationalizing gender? Strategic interventions and gba+practice in Canada. Can J Political Sci 50: 427-442.

FLOOD M, GARGINER JK \& PRINGLE K. 2007. International encyclopedia of men and masculinities. Routledge, London.

FORUM WE. 2018. The global gender gap report 2018. http://www3.weforum.org/docs/WEF_GGGR_2018.pdf.

Accessed: 15-08-2018.

GOLDIN C. 1980. The work and wages of single women, 1870-1920. J Econ Hist 40: 81-88.

GOLDIN C. 2006. The quiet revolution that transformed women's employment, education, and family. Am Econ Rev 96: 1-21.

HUNT V, LAYTON D \& PRINCE S. 2015. Diversity Matters: McKinsey and Company Report. http://www.mckinsey. com/business-functions/organization/our-insights/ why-diversity-matters. Accessed: 2017-18-01.

IBGE. 2019. Conheça a população do brasil: Quantidade de homens e mulheres. https://educa.ibge.gov. br/jovens/conheca-o-brasil/populacao/18320quantidade-dehomens-e-mulheres.html. Accessed: 05-08-2020.

LAGERBERG F. 2016. Women in business report. https://www.grantthornton.com.br/globalassets/ _markets_/bra/media/arquivos-industrias/estudos/ gt_wib_turning_promise_into_practice_online.pdf. Accessed:23-10-2019.

LESER CEV. 1958. Trends in women's work participation. Popul Stud 12: 100-110.

LIMA BS, BRAGA MLDS \& TAVALRES I. 2016. Participação das mulheres nas ciências e tecnologias: entre espaços ocupados e lacunas. Rev Gen 16: 11-31. 
LOMBARDI MR, BRUSCHINI MC \& MERCADO CM. 2009. AS mulheres nas forças armadas brasileiras: A marinha do brasil 1980-2008. FCC 30: 1-105.

LÜCHMANN HH \& ALMEIDA CCR. 2010. A representação política das mulheres nos conselhos gestores de políticas públicas. Rev Katál 13: 86-94.

MILKMAN R. 1987. Gender at Work:The Dynamics of Job Segregation by Sex during World War II. University of Illinois Press, Champaign.

MORRISON AM, WHITE RP \& VAN VELSOR E. 1987. Breaking the Glass Ceiling: Breaking the Glass Ceiling: Can Women Reach the Top of America's Largest Corporations? Addison-Wesley.

MOSCHKOVICH M \& ALMEIDA AMF. 2015. Desigualdades de gênero na carreira acadêmica no Brasil. Dados 58: 749-789.

MUSUMECI L \& SOARES BM. 2004. Polícia e gênero: Participação e perfil das policiais femininas nas polícias militares brasileiras. Rev Gen 5: 183-207.

OFFICE IL. 2018. Global wage report 2018/19. https:/ / www. ilo.org/wcmsp5/groups/public/---dgreports/---comm/ ---publ/documents/publication/wcms_650553.pdf. Accessed: 18-09-2019.

OLINTO G. 2011. A inclusão das mulheres nas carreiras de ciência e tecnologia no Brasil. Inc. Soc., Brasília.

OLIVEIRA A. 2012. Burocratas da linha de frente: executores e fazedores das políticas públicas. Revista de Administração Pública 46: 1551-1573.

PALOTTI P \& ALESSANDRO F. 2015. Servidores públicos federais: novos olhares e perspectivas. Escola Nacional de Administração Pública 42: 133. https: // repositorio.enap.gov.br/bitstream/1/2237/1/009.pdf. Accessed: 29-06-2021.

RIFORGIATE SE \& BOREN JP. 2015. “I just can't clean the bathroom as well as you can!": Communicating domestic labor task equity-resistance and equity-restoring strategies among married individuals. J Fam Commun 15: 309-329.

SAITOVICH EB, LIMA B \& BARBOSA MC. 2015. Mulheres na física: Por que tão poucas? In: Saitovich EMB, Funchal RZ, Barbosa MC, de Pinho SRR \& Santana AE (Eds), Mulheres na Física. Livraria da Física, São Paulo.

SCHWEITZER MM. 1980. World War II and female labor force participation rates. J. Econ Hist 40: 89-95.

VADNJAL J \& ZUPAN B. 2009. The role of women in family businesses. Econ Bus Rev 11: 159-177.
VAZ DV. 2010. Segregação hierárquica de gênero no setor público brasileiro. http://repositorio.ipea.gov.br/ handle/11058/4004. Accessed: 05-08-2020.

\section{How to cite}

SILVA RPA, NODARI CA, CARDOSO M, SANTANA AE \& BARBOSA MC. 2021. Misogyny in Brazilian Federal Government Agencies for Science and High-Education. An Acad Bras Cienc 93: e20201389. DOI 10.1590/0001-3765202120201389.

Manuscript received on August 27, 2020;

accepted for publication on October 12, 2020

\section{ROBERTA PEIXOTO ARÊAS DA SILVA ${ }^{1}$}

https://orcid.org/0000-0003-4385-4623

\section{CAROLINA ANDRÉA NODARI ${ }^{1}$}

https://orcid.org/0000-0002-4903-774X

\section{MANOEL CARDOSO ${ }^{1}$}

https://orcid.org/0000-0002-2575-5472

ADEMIR E. SANTANA ${ }^{2}$

https://orcid.org/0000-0003-0065-797X

MARCIA C. BARBOSA ${ }^{3}$

https://orcid.org/0000-0001-5663-6102

${ }^{1}$ CAPES, Ministério da Educação, Setor Bancário Norte, Quadra 2, Bloco L, Lote 06, 70040-020 Brasilia, DF, Brazil

${ }^{2}$ Universidade de Brasília, Centro Internacional de Física, Instituto de Física, 70910-900 Brasília, DF, Brazil

${ }^{3}$ Universidade Federal do Rio Grande do Sul, Instituto de Física, Av. Bento Gonçalves, 9500, 91501-970 Porto Alegre, RS, Brazil

\section{Correspondence to: Roberta Peixoto Arêas da Silva}

E-mail: roberta.silva@capes.gov.br

\section{Author contributions}

RAPS, CAN and MC conceived the project collected the original data, worked in the analysis, participate in the writing and in the conclusions. AES worked in the analysis, participate in the writing and in the conclusions. MCB conceived the project, produced the graphs, worked in the analysis, participate in the writing and in the conclusions.

\section{(cc) BY}

